\title{
UNDERSTANDING AND DESCRIBING RELATIONSHIP OF STATE LAW AND HUMAN RIGHT
}

\author{
Dany Tri Hutabarat ${ }^{1}$, Zenny Fransisca ${ }^{2}$, Fauziah Ritonga ${ }^{3}$, Dinda Julita Pardede ${ }^{4}$, Salsabila \\ Almas $^{5}$, Nandra Astuti Sikumbang ${ }^{6}$, Mutiara ${ }^{7}$, Anggi Khoiriyah ${ }^{8}$, Siti Hamizah $^{9}$, \\ Malahayati $^{10}$, Suryadi ${ }^{11}$ \\ 1-11 \\ Universitas Asahan \\ E-mail: ${ }^{1)}$ danytryhutamahutabarat@gmail.com, ${ }^{2)}$ zennyfransisca899@gmail.com, ${ }^{3)}$ \\ fauziahritonga5@gmail.com, ${ }^{4}$ dindajulitapardede8@gmail.com, ${ }^{5)}$ Huatkoi11@icloud.com, ${ }^{6}$ \\ nandran28@gmail.com, ${ }^{7}$ mut650402@gmail.com, ${ }^{8)}$ anggikhoiriyah@gmail.com, ${ }^{9}$ \\ hamizahsiti344@gmail.com, ${ }^{10)}$ Malahayatiputri2003@gmail.com, ${ }^{11)}$ yadikisaran7@gmail.com
}

\begin{abstract}
Human rights are a natural right that a person is born with; they cannot be taken away and their existence cannot be denied; in addition, human rights serve as accolades. Human rights and the rule of law are inextricably linked, and the rule of law, of course, prioritizes and defends human rights. The function of the law itself is to safeguard humans while they pursue their varied interests, with the caveat that individuals must also consider the interests of others in their pursuit of their own interests. In addition to the protection provided by the law, we have the right to protection from the government. The existence of a state of law signifies that both the state and society acknowledge the importance of human rights protection and guaranteeing their fulfillment. It will be possible to impose the appropriate punishment if a breach of human rights occurs in this manner. It is necessary to understand the relationship between the state of law and human rights in order to prevent human rights breaches from occurring.
\end{abstract}

Keywords: State Relations, Law, Human Rights

\section{INTRODUCTION}

Humans are creatures created by God Almighty in all of their perfection, and they are the most perfect of all. Humans have been endowed with inherent rights that must be respected by others since the moment of their creation and birth; these rights are collectively referred to as human rights. In light of the fact that humans are God's creation, human rights are a gift from God, and as a result, they cannot be taken or eliminated by the government. The state is required to carry the responsibility of, or be accountable for, ensuring that all of its citizens' human rights are respected, fulfilled, and protected.

By definition, rights are normative elements that function as guidelines for behavior, protecting freedom (Busthami, 2018), immunity, as well as guaranteeing the opportunity for humans to maintain their dignity (Tahira, 2020). The rights have the following elements; the right owner, the scope of the right owner and the parties willing to implement the rights. These three elements are united in the basic sense of rights.

The development of human rights law at this time can be said to be quite progressive (Amira \& Adilah, 2019), this can be seen that a number of laws and regulations relating to or concerning human rights have been produced and a number of international legal instruments regarding human rights. 
Human rights cannot be revoked, which means that regardless of how horrible a person's actions and treatment are, he or she will retain their humanity and, as a result of their human rights (Aswandi \& Roisah, 2019). As a response, citizens who do not respect and seize the rights of others must be dealt with harshly in order to restore order and ensure that everyone's rights are protected (Lahera \& Dewi, 2021). In this case, the role of the rule of law has a very close relationship, and is expected to be able to overcome and ensure that everyone's rights are guaranteed.

Whether intentional or unintentional or negligent, any act by a person or group of people including the state apparatus that unlawfully restricts the human rights of a person or group and does not or is likely to not receive a fair legal settlement is a violation of human rights, and the applicable legal mechanism in Article 1 point 6 of Law 39 of 1999 concerning Human Rights must be followed.

Human rights and the rule of law are conceptions of humanity and social relations that have been born since the history of human civilization (Indriyani, 2017). Human rights and the rule of law can also be interpreted as efforts and results of human struggle to maintain and achieve human dignity.

\section{RESEARCH METHODS}

The method used in this paper is the literature method, namely by using a series of activities related to the methods of collecting library data, reading, and taking notes, as well as managing research materials.

\section{RESULTS AND DISCUSSION}

\subsection{Rule of Law in Indonesia}

Law exists in social life with the embodiment of regulations that regulate humans in dealing with one another (Matompo et al, 2018). The existence of law in society is not only defined as a means of regulating human relationships or interactions so that they become orderly, but can also be used as a means of changing people's patterns of thinking and behavior (Indriyani, 2017; Khairazi, 2015). Law as a collection of rules or rules has content that is general and normative, general because it applies to everyone and normative because it determines what should be done, what should not be done or must be done and determine how to implement compliance with the rules (Samekt, 2009).

In general, law is defined as a regulation regarding human behavior in society that has witnesses who are forced, and serves to regulate and harmonize the implementation of different interests among members of the community, and has a nature that can be imposed with sanctions.

Muhammad Yamin defines a legal state as a state that runs a government that is not according to the will of the people in power, but according to written rules made by the people's representative (DPR) which are legally formed and accordance with the existing principle (Supratman, 2012). 


\section{JOURNAL OF HUMANITIES, SOCIAL SCIENCES AND BUSINESS (JHSSB) \\ VOLUME 1 ISSUE 1 (2022)}

The Indonesian constitution has proven that Indonesia is a state of law because the 1945 Constitution has explicitly stated that Indonesia is a state of law and has included regulations on human rights. In the course of the republic of Indonesia, the history of human rights has been thought by the founder of the country with the conditions that were recorded at that time as illustrated in the debate in the BPUPKI session between Soekarno and Soepomo on the one hand with Moh. Hatta and Moh. Yamin on the other hand which is an important history in the development of Human Rights in Indonesia.

When discussing the legal system, it is important to know what it stands for in advance. To describe the legal system, Professor Soebekti uses the term "order," which refers to how the many components of the system are connected and structured in accordance with a plan or pattern (Rizky, 2013). The legal system is consistent. It is desirable that no legal regulations conflict with one another.

Indonesia is a legal state which is written in the 1945 Constitution article 1 paragraph 3 which contains that the Indonesian state is a legal state. The state of law adopted by Indonesia is a legal state that always considers all actions on two grounds, namely in terms of use and purpose in terms of its legal basis.

Furthermore, the law of state has several characteristics, namely:

1. Having restrictions on state power to individuals, those restrictions are carried out by law;

2. Violations of individual rights may only be based on the rule of law/legality principles;

3. There is protection of human rights/natural rights;

4. There is a separation of powers;

5. An impartial judiciary.

The existence of human rights as one of the main elements of the rule of law can be seen in the international commission of lurist, which states that the main principles or elements of the rule of law are as follows:

1. The rule of law is subject to the law;

2. The government must respect individual rights under the rule of law;

3. Judges must be guided by the rule of law, protect and run without fear of their freedom as judges.

\subsection{Human Rights in Indonesia}

The definition of Human Rights in Article 1 of the Human Rights Act is a set of rights inherent in the nature of human existence as a creature of God Almighty and is a gift that must be respected, upheld, and protected by the state, law, government, and every people for the honor and protection of human dignity.

Human Rights according to A. Masyhur Effendi, can be interpreted as sacred basic rights that are inherent to everyone in humans, given by God forever, when using them does not harm the basic rights of other members of the community (Sabila et al., 2019). 
By definition, rights are normative elements that function as guidelines for behavior, protect freedom, immunity, and guarantee opportunities for humans to maintain their dignity. Rights have the following elements; the right owner, the scope of the right owner and the parties willing to implement the rights. These three elements are united in the basic sense of rights.

Moreover, definition of Human Rights according to law number 39 of 1999; Human Rights are a set of rights that are inherent in the nature and existence of every human being as a creature of God Almighty and his gifts that must be respected, upheld, and protected by the state, law, government and everyone for the sake of honor and protection of human dignity.

The essence of human rights, humans are creatures created by God Almighty with all its perfection. One of them is reason and mind that distinguishes it from other creatures (Siallagan, 2016). Since being created and born, humans have been given rights that are inherent in themselves and must be respected by other humans. These rights are also known as human rights. Human rights consist of two of the most fundamental rights, namely the right to equality and the right to freedom. Without these rights, it will be very difficult to enforce other human rights. Recognition of human rights is essentially an appreciation of all potential and human dignity according to their nature.

The origin of the idea of Human Rights as described above comes from the natural rights theory.

The characteristics of Human Rights are:

1. Human rights do not need to be granted, purchased, or inherited;

2. Human rights are part of human automatically;

3. Human Rights apply and are owned by all humans, regardless of gender, race, religion, ethnicity, political views, or social origin, nation. All humans are born with the same dignity; and

4. Human rights cannot be violated, revoked, or abolished even if a country makes laws that do not protect or violate them.

Apart from being universal, human rights are also inalienable which mean that no matter how bad a person's actions and treatment are, he will not stop being human, and because of that, he still has human rights. In other words, that these human rights are inherent in him as a human being.

\subsubsection{Human Rights Principles}

\section{The principle of Equality}

Humans have equality in human rights where the principle of equality emphasizes that humans are equal in terms of their dignity as human beings. The principle of equality is the most fundamental principle of human rights.

2. The principle of Non-Discrimination

The prohibition against discrimination is an important part of the principle of equality. If all people are equal, then there should be no discriminatory treatment other than 


\section{JOURNAL OF HUMANITIES, SOCIAL SCIENCES AND BUSINESS (JHSSB) \\ VOLUME 1 ISSUE 1 (2022)}

affirmative action taken to achieve equality. The principle of non-discrimination is a central concept in human rights principles.

\section{State Obligations}

The principle of state obligations arises as a logical consequence of the existence of the principle provisions according to international human rights law that the individual is the party holding human rights while the state is the holder of the obligation to human rights, namely the obligation to protect, respect, and fulfill.

Violation of human rights is every act of a person or group of people including state apparatus, whether intentional or unintentional or negligence which unlawfully reduces, hinders, limits or revokes the human rights of a person or group of people (Hermawan Usman, 2014) guaranteed by law, and do not get or fear that they will not get a fair and correct legal settlement based on the legal mechanism that applies in Article 1 point 6 of Law no. 39 of 1999 concerning Human Rights. The following are some examples of human rights violations that are both deragoble and non-deragoble.

1) Derogable human rights violations;

2) Violations of gathering, meeting, and associating in Article 24 of Law no. 39 of 1999 concerning Human Rights;

3) Violation of the right to express opinions in public, the right to strike article 25 of Law no. 39 of 1999 concerning Human Rights;

4) Violation of the right to freedom of movement and residence within the territory of the Republic of Indonesia Articles 17 and 40 of Law no. 39 of 1999 concerning Human Rights;

5) Violation of the right to a sense of security articles 30 and 35 of Law no. 39 of 1999 concerning Human Rights;

6) Non-derogable human rights violations;

7) Violation of the right to life article 9 of Law no. 39 of 1999 concerning Human Rights;

8) Violation of the right not to be tortured Article 33 paragraph 1 of Law no. 39 of 1999 concerning Human Rights;

9) Violation of the right to freedom of person, thought, conscience, articles 15 and 23 of Law no. 39 of 1999 concerning Human Rights;

10) Violation of religious rights article 22 of Law No.39/1999 on human rights.

\subsection{The Relationship of State Laws and Human Rights}

Human rights are gifts from God, as a result of humans' status as God's creation, and as such, they cannot be taken away or repealed by the state. The state is required to carry the responsibility of, or to be accountable for, the respect, fulfillment, and protection of human rights for all of its citizens, regardless of race, religion, or national origin.

The relationship between the state law and human rights is interconnected, very close and cannot be separated because a law functions to protect human rights, thus all human behavior in a country is always based on law and all is bound by law and evidence that the law binds it. 
The development of human rights cannot be separated from the state law, because one indication to be called a state of law, which is the enforcement of human rights, because a state of law without acknowledging, respecting and implementing the principles of human rights cannot be called a state law.

Human rights and the state law cannot be separated, in fact thinking legally is related to the idea of how justice and order can be realized. Thus, the recognition and inauguration of the rule of law (Arliman, 2019) one of its objectives is to protect human rights which mean the rights and freedoms of individuals are recognized, respected, and upheld by the government, including the people.

It is necessary to establish legal restrictions on the rights and freedoms of every citizen with the express objective of ensuring the acknowledgment and respect of human rights. Consequently, it is apparent that the job of the law in this context is not just to limit the power of government, but also to limit the freedom of the community, and that this duty is carried out democratically.

The evolution of human rights law in Indonesia has been described as "progressive," as evidenced by the production of a number of laws and regulations relating to or involving human rights, as well as the ratification of a number of international human rights treaties by the country.

Although the Universal Declaration of Human Rights does not have legal force, it does have moral force, and the provisions contained in it are good and considerate in national legislation in various countries, and they have even become a parameter for assessing the extent to which a country guarantees the protection of human rights in its constitution. As a matter of fact, the provisions of the Universal Declaration of Human Rights can be considered to have value as customary international law under certain circumstances.

\section{CONCLUSION}

Human rights are gifts from God, as for the consequences of humans, namely God's creation, so that the State is obliged to bear the burden or be responsible and protect human rights for all citizens. The relationship between the state of law and human rights is interconnected, very close and cannot be separated because a law functions to protect human rights, thus all human behavior in a country is always based on law and all is bound by law and evidence that the law binds it.

\section{REFERENCE}

Amira, \& Adilah. (2019). Perkembangan dan Penerapan Hukum Administrasi Negara di Indonesia. Ilmu Administrasi Publik Universitas Sriwijaya.

Arliman. S, L. (2019). Mewujudkan Penegakan Hukum Yang Baik Di Negara Hukum Indonesia. Dialogia Iuridica: Jurnal Hukum Bisnis Dan Investasi, 11(1). https://doi.org/10.28932/di.v11i1.1831 


\section{JOURNAL OF HUMANITIES, SOCIAL SCIENCES AND \\ BUSINESS (JHSSB) \\ VOLUME 1 ISSUE 1 (2022)}

Aswandi, B., \& Roisah, K. (2019). Negara Hukum Dan Demokrasi Pancasila Dalam Kaitannya Dengan Hak Asasi Manusia (HAM). Jurnal Pembangunan Hukum Indonesia, 1(1). https://doi.org/10.14710/jphi.v1i1.128-145

Busthami, D. (2018). Kekuasaan Kehakiman Dalam Perspektif Negara Hukum Di Indonesia. Masalah-Masalah Hukum, 46(4). https://doi.org/10.14710/mmh.46.4.2017.336-342

Hermawan Usman, A. (2014). Kesadaran Hukum Masyarakat Dan Pemerintah Sebagai Faktor Tegaknya Negara Hukum Di Indonesia. Jurnal Wawasan Hukum, 30(1).

Indriyani, D. (2017). Hak Asasi Manusia dalam Memperoleh Pendidikan. Jurnal Pendidikan Hukum, Politik Dan Kewarganegaraan., 7.

Khairazi, F. (2015). Implementasi Demokrasi dan Hak Asasi Manusia di Indonesia. Inovatif: Jurnal Ilmu Hukum, 8(1).

Lahera, T., \& Dewi, D. A. (2021). Hak Asasi Manusia: Pentingnya Pelaksanaan Dan Penegakan Hak Asasi Manusia Di Indonesia Saat Ini. Journal Civics \& Social Studies, 5(1). https://doi.org/10.31980/civicos.v5i1.1055

Matompo, O., \& dkk. (2018). HUKUM dan Hak Asasi Manusia. Jatim: Intrans Publishing.

Rizky, A. (2013). Hukum,Hak Asasi Manusia Dan Demiokrasi. Yogyakarta: Graha Ilmu.

Sabila, Y., Bustamam, K., \& Badri, B. (2019). Landasan Teori Hak Asasi Manusia Dan Pelanggaran Hak Asasi Manusia. Jurnal Justisia : Jurnal Ilmu Hukum, PerundangUndangan Dan Pranata Sosial, 3(2). https://doi.org/10.22373/justisia.v3i2.5929

Samekt, A. (2009). Negara dalam dimensi Hukum Internasional. Bandung: PT CITRA .

Siallagan, H. (2016). Penerapan Prinsip Negara Hukum Di Indonesia. Sosiohumaniora, 18(2). https://doi.org/10.24198/sosiohumaniora.v18i2.9947

Supratman, M. (2012). Pengadilan HAM di Indonesia. Jakarta: ERLANGGA.

Thahira, A. (2020). Perkembangan Negara Hukum Demokrasi Ditinjau Dari Aspek Penegakan Hukum Administrasi Lingkungan Hidup Di Indonesia. Jurnal Selat, 7(1). https://doi.org/10.31629/selat.v7i1.1847 
